\title{
Rectal Tube
}

National Cancer Institute

\section{Source}

National Cancer Institute. Rectal Tube. NCI Thesaurus. Code C122600.

A hollow tube that is directed into the colon from the rectum. 